Publisher homepage: www.universepg.com, ISSN: 2663-7820 (Online) \& 2663-7812 (Print)

https://doi.org/10.34104/cjbis.020.01050119

Canadian Journal of Business and Information Studies

Journal homepage: http://www.universepg.com/journal/cjbis

\title{
Green Banking in the Way of Sustainable Development: An Overview of Practice and Progress in Bangladesh
}

\section{Mohammad Ahsan Ullah*}

Department of Management Studies, Comilla University, Cumilla-3506, Bangladesh.

*Correspondence: ahsanctgbd71@gmail.com (Dr. Mohammad Ahsan Ullah, Professor, Department of Management Studies, Comilla University, Cumilla-3506, Bangladesh).

\section{ABSTRACT}

The main objective of the study is to evaluate the practice and progress of the activities of green banking in the way of sustainable development of Bangladesh. Green banking is regarded as sustainable banking, which has a role to safeguard the planet from environmental degradation, with an aim of ensuring sustainable development. It comprises the choices that take sustainability into account. Sustainable development is an expansion that comes across the requirements of the present situation without overlooking the capacity of the future situations to meet the necessities. Bangladesh is in need of proper adaptation and utilization of green banking for its sustainable development. The present study is conceptual and analytical in nature based on the secondary data with an extensive literature survey along with scanning the annual and quarterly reports of Bangladesh Bank on green banking during 2011-2019 fiscal years. The secondary sources of data are internet and commercial banks websites, Bangladesh Bank (BB) websites and literature reviews, etc. The collected data are analyzed and interpreted in the light of the practice and progress of activities of green banking in Bangladesh from a global perspective. The study shows that banking in Bangladesh is to the diversification phase passing through the intensification and foundation phases. It is progressing steadily. They have a lot more scope to contribute in the diversification of green finance in the way of sustainable development of Bangladesh. Rigorous, effective, and coherent efforts from banks in this regard are the demands of the day.

Keywords: Bangladesh, Sustainable development, Environment, Practice, Progress, Bank, and Green banking.

\section{INTRODUCTION:}

Green banking is gaining fast global acceptance as a standard to assume environmentally sustainable and socially acceptable business practices. This banking is eco-friendly in stopping the degradation of environment so that the planet can be more habitable. It helps in using all of the bank's resources with responsibility and care. It also comprises choices that take sustainability into account with a view to avoiding waste and giving emphasis on priority (Rahman and Perves, 2016). Green banking has become a buzzword in the sustainable banking throughout the world over the last UniversePG I www.universepg.com few decades. In fact, green banking is regarded as sustainable banking, which has a role to safeguard the planet from environmental degradation, with the aim of ensuring economic growth which is sustainable (Islam et al., 2020). Sustainable development, on the other, has been emerged as a new paradigm of the development in achieving the overarching development goal since 1992. It was first introduced by the Bruntland Commission in its report entitled "Our Common Future" in 1987 (NSDS, 2021). In a broader sense, sustainable development is the "long-term cultural, economic and environmental health and 
vitality" with emphasis on long-term, "together with the importance of linking our social, financial, and environmental wellbeing." The principle of sustainable development appeals to enlightened self-interest often involving the triple bottom line of economic, social and environmental performance (Rahman and Rahman, 2020). In fact, sustainable development is an expansion that comes across the requirements of the present without negotiating about the capacity of future generations to meet their own necessities (Smith and Rees, 1998).

Bangladesh is the most climate change vulnerable country in the world. It is facing a lot of environment deteriorating problems like air pollution, water pollution and scarcity, deforestation, increasing disaster risk and loss of biodiversity. That is why, side by side of global development and response to the environmental degradation, the banking sector of Bangladesh can play the important role in this regard. So, Bangladesh is in need of proper adaptation and utilizeation of green banking for its sustainable development (Saha et al., 2020). Banking sector is in the unique position of the economic activities. The developed countries of the world started the practice of green banking long ago although Bangladesh started its practice in the recent years. Bangladesh Bank (BB) is trying to its level best in this regard. To put into practice of green banking, $\mathrm{BB}$ has developed the rules of green banking in the year 2011 and BB is the world's first central bank, which has in-depth and obvious awareness on green banking. All banks like Public, Private and Foreign banks, etc. are functioning thoroughly on green banking as initiated by BB. As per BB's data, all planned banks have developed their own green banking policy and green banking unit. Besides, it also created congenial atmosphere for the banking sector to ensure profound impact of green banking on socioeconomic landscape of Bangladesh. Hence, the main objective of the study is to evaluate the practice and progress of activities of green banking in the way of sustainable development of Bangladesh.

\section{Review of Literature}

Review of theories and studies is a must in conducting a research. This is necessary to identify the knowledge gap in the proposed field of study. In this field of research, a few relevant theories and studies on green UniversePG I www.universepg.com banking, and its regulation and disclosure in the developing and developed countries have been emphasized. The green practice and progress of Bangladeshi banking companies along with $\mathrm{BB}$ regulations in the way of sustainable development of Bangladesh are also intensely reviewed.

2.1 Review of Relevant Theories - In today's competitive business world, no business can achieve its ultimate goal of earning profit without considering the factors or forces that directly or indirectly affect it or its surroundings. It has to deal with such forces as stakeholders, legitimacy, institutional and societal forces available in the society. Green banking is the production of that reality. It will be able to lead Bangladesh towards its sustainable development only when it can maintain stakeholders' expectations, iron law of legitimacy, institutional and social forces that a society holds at a given time. Hence, approaches to green banking towards the sustainable development of Bangladesh should always focus on the aspects of social reality like stakeholder, legitimacy, institutional and societal theories. These relevant theories in this regard are described below:

Stakeholder Theory: Stakeholder theory suggests that organizational survival and success is contingent on satisfying both its economic and non-economic objectives by meeting the needs of the company's various stakeholders. Generally, stakeholders refer to a diverse group of people including national and international bodies (Masud et al., 2017). Moreover, strong national and international environmental groups, international donor agencies, and funding organizations encourage organizations to invest in the area of environmental pollution, environmental innovation, green products, environmental manage-ment system, and appropriate utilization of natural resources (Chen et. al., 2015; Perrault \& Clark, 2016, \& Delgado et. al., 2016). Hence, banks produce more green products in the multi-stakeholders' pressures to protect their investment and reputation with improved satisfaction of customers.

Legitimacy Theory: Legitimacy theory explains the relationship between organizations and society in terms of social norms and values. According to the legitimacy theory, organizations and society work for each other. Their relationship is based on the value 
system of the society (Gray et al., 1996; Khan et al., 2013; Ntim et al., 2013). Banking companies are practicing green guidelines and ensuring green disclosure to reduce the legitimacy gap between organizations and society (Bose et al., 2017).

Institutional Theory: All organizations operating in institutional environments are motivated to interact with social expectations and abide by social norms, rules, procedures, and regulations (Oliver, 1991). Institutionalization is the process of shared information between an individual and society. In fact, it is the combination of developed and learned processes with an organization and within society (Dillard-Marquez et al., 2004). Banking companies are incorporating green guidelines owing to institutional pressures and are employing green disclosure to be more legitimate in society. Institutional pressures encourage managers to seek environmental sustainability (Ortiz-de-Mandojana et al., 2016). Regulatory and normative pressures engage organizations in more green innovations (Berrone et al., 2013). Coercive or regulatory pressures, such as laws and regulations of different bodies oblige organizations to change their structure. Governmental laws, regulations, and social requirements are important and influential drivers of environmental management practices (Chen et al., 2015). The green guidelines of Bangladesh Bank, therefore, have sufficient influence on the banking companies of Bangladesh in maintaining the institutional legitimacy.

Social Contract Theory: The philosophers like Thomas Hobbes, John Locke and Jean Jacques Rousseau talked on social contract. Rousseau (Rousseau, 1987), in fact, conceptualized the individual-society relationship as a symbiotic situation whereby the two parties mutually confer some right to the state in order to maintain social order which makes human life and cohabitation better and to gain benefits of community and safety. Businesses are bound by the social contract whereby they consent to perform various socially desired actions in return for approval of their objecttives and other rewards. This ultimately guarantees its continued existence.

2.2 Review of related studies - Review of studies is very common in any research. Related studies on green banking are reviewed, in order to find out knowledge gap, in the way of sustainable development of BanglaUniversePG I www.universepg.com desh. Bihari (2011) regarded green banking as socially responsible banking activities start with the aim of protecting the environment; before granting any loan for any project at first, this banking considers the environmental aspects of the project, at present or even in future environmental safety. Goyal and Joshi, (2011) highlighted some social and ethical issues in banking like-disbursement of loan only to those organizations which have environmental concerns and finally, it can facilitate the achievement of sustainable development of banking. Weber and Remer (2011) said that green banking is a value-driven banking system that can appeal the interest of clients looking for safe and sensible ways to deposit their money, attract conventional banking towards social banking. Bahl, (2012) found that this type of banking can help the business and society by saving time, energy and cost. It reduces paperwork, creates awareness to business people regarding the environment of the greater society.

Ahmad et al. (2013) confirmed that one of the major factors of practicing green banking in Bangladesh is to ensure economic sustainability which is imposed by Bangladesh Bank. Choudhury et al. (2013) said that every bank should take the initiative to develop the new green product with greater involvement of stakeholders and environmental sustainability in today's banking competition. Dharwal and Agarwal, (2013) argued that green banking is a key to mitigate different types of risks like-the credit risk, legal risk, and reputation risk. The authors also had suggested some green practices carbon credit business, green financial products, green mortgages, carbon footprint reduction, energy consciousness, green buildings and social responsibility services towards the society. Meena, (2013) identified four benefits of green banking-reducing deforestation, creating environmental awareness among employees and customers, providing loans at a lower rate, changing business activities in a manner that is environmentally friendly. Ullah, (2013) said that Bangladesh, a least developed country in the world, is the worst sufferer of world environmental pollution through industrialization of the western countries.

Chaurasia, (2014) found that there have not been many initiatives in green banking in India and investigators suggested that bank should practice greener and 
consider ecological aspects as a part of their lending principle, which would force industries to go for mandated investment for environmental management for the greater society. Hossen et al. (2014) argued that as a part of e-commerce, green banking can ensure the environmental sustainability by ensuring the online banking and e-banking by following the 3D approachDe-materialization, De-carbonization, and De-mobilization in the daily activities of the bank. Argenti, (2015) examined the potential influence of perceived green value on green trust and green loyalty and the effect of green trust on green loyalty. Chowdhury and Dey, (2016) said that BB has developed the regulations of green banking in the year 2011 and banks in Bangladesh have enthusiastically responded to BB's guidelines towards green banking. Rahman and Perves, (2016) argued that Bangladesh is one the most environ-mentally inclined country in the world; keeping this in mind, BB established a green banking policy in 2011. This study not only goes to focus on the present condition of the banks in observing with BB policy to save the environment but also to increase financial sustainability. Green banking activities include using all of the bank's resources with responsibility and care. It also comprises the choices that take sustainability into account.

Masud et al. (2017) recognized that Bangladesh has 29 environmental policies although the country's environmental situation is the most sensitive on a global circumstance. BB presented its final simplified version of green guidelines in 2013 and affirmed the objective of green reporting globalization by introducing Global Reporting Initiative (GRI) and external confirmation of the report from 2015. GRI guidelines are established on the idea of the triple bottom line while BB's green reporting rules mostly cover an environmental methodology. Furthermore, it is also considered that GRI guiding principles are the most frequently and extensively used sustainable reporting construction for the assessment, arrangement, and reporting of sustainability performances of both developed and developing countries.

Chen et al. (2018) considered the green approach one of the few concepts that has been identified to be appropriate in the delivery of banking products and services for the greater good of mankind. Iqbal et al.
(2018) said that the need for the adoption of green banking practice is considered to be very important because of its environmental, corporate and social benefits. Masud and Kim, (2018) said that climate change is the most pressing issue in the global context. Bangladesh is in the most vulnerable situation. Bangladesh will suffer significant losses if the situation does not change. The assessment is that by 2050 , the annual loss will be $2 \%$ and the gross domestic product $9.4 \%$ (GDP) by 2050 while the country is responsible for less than $0.35 \%$ of global carbon emissions. Sellitto et al. (2019) proposed to enable management in training employees in accordance with the principle of green practices. Banks are recommended to improve on their green performance through "collaboration, innovation, operation, and mitigation" measures.

\section{METHODOLOGY:}

The present study is conceptual and analytical in nature based on the secondary data with an extensive literature survey along with scanning the annual and quarterly reports of Bangladesh Bank (BB) on green banking during 2011-2019 fiscal years. The secondary data have been collected from internet and commercial banks websites, BB websites and literature reviews etc. Different books and journal articles have been pursued in enriching the literature of the study. To find out various green banking practices nationally and internationally, the websites of the respective banks have been utilized and studied. An intensive desk study has also been undertaken in constructing the theoretical framework of the study. To get the clear idea about green banking, its application in Bangladesh and elsewhere of the world, the researcher has conducted an informal interview of some professional bankers to show the real scenario of green banking, its practice and progress. The collected data are analyzed and interpreted in the light of practice and progress of activities of green banking in Bangladesh from the global perspective.

\section{ANALYSIS AND FINDINGS:}

5.1 Analysis of Sustainable Development Policy
Initiatives by Bangladesh Bank - Bangladesh Bank (BB) started its policy intervention on environment friendly banking practices by issuing Environmental 
Risk Management (ERM) guidelines for banks in 2011. In the same year it issued green banking policy guideline for banks. In 2012, a uniform reporting format for reporting green banking activities in a structured manner for banks was introduced, whereas in the subsequent year in 2013, policy guidelines for green banking was also issued for the scheduled banks in 2013. Through these guidelines all banks were brought under the structured reporting system. Besides, to expedite the ongoing initiatives of banks at faster pace, from January 2016 onwards minimum target of direct green finance was set at $5 \%$ of the total funded loan disbursement for all banks. BB instructed all banks to establish sustainable finance unit and sustainable finance committee by abolishing both green banking and CSR units on December 1, 2016.

Guidelines on Environmental and Social Risk Management (ESRM) for banks in Bangladesh along with an Excel-based Risk Rating Mode (ERRM) have been issued which has become enforceable from January 01, 2018 replacing the guidelines on ERM to all extent. Recently, a comprehensive list of product or initiatives of green finance for banks has been circulated in September, 2017. To monitor green banking policy and other regulations and to ensure the quality \& uniformity of data provided by banks, a new uniform reporting format of quarterly review report on green banking activities has been circulated for banks in January, 2018. To ensure the movement towards sustainability, banks were instructed to form a 'Climate Risk Fund (CRF)' having allocation at least $10 \%$ of their CSR budget for CRF. This funding can be done in both ways by providing grants or financing at reduced rate of interest. Meanwhile, banks have been instructed to set up solid waste management system, rainwater harvesting and solar power panel in their newly constructed or arranged building infrastructure. Besides, BB instructed all the banks to ensure the establishment and activeness of Effluent Treatment Plant (ETP) during financing to all possible clients.

BB has introduced refinance scheme funded by excess liquidity of Sariah based financial institutions to facilitate the Sariah based banks in the country. This refinance scheme aims to encourage the Sariah based investors to be involved more in the renewable energy and environment friendly efforts, and strengthen the UniversePG I www.universepg.com involvement of Sariah based financing in this sector. $\mathrm{BB}$ intends to provide long term financing for private sector firms, mainly mid-size manufacturing firms under the Financial Sector Support Project (FSSP) financed by the International Development Association (IDA) of the World Bank group. An Environmental and Social Management Framework (ESMF) has been developed to ensure the sustainability of financing of this facility. In January 2016, a new longer-term refinancing window named Green Transformation Fund (GTF) was launched to ensure sustainable growth in export oriented textile and leather sectors conducive to transformation of green economy in the country. To further fortify the financing arrangement under GTF, it was decided to provision for a participation agreement to be signed between BB and intended banks. In 2019, investment by scheduled banks in any impact fund which is registered under BSEC (Alternative Investment) Rules, 2015 and formed for environment friendly sectors was considered as green finance (Appendix 1)

\subsection{Analysis of Sustainable Development Initiatives by Bangladesh Bank (BB)}

\subsubsection{BB Refinance Scheme for Environment Frie-} ndly Products or Initiatives - To broaden the financeing avenue for green products like solar energy, biogas plant and Effluent Treatment Plant (ETP), etc., BB established a revolving refinance scheme amounting to Tk. 2 billion (200 crore) from its own fund for solar energy, Bio-gas and ETP in 2009 (Appendix 2). The product line has been enhanced to 51 under 08 categories. Since inception, total amount of Tk. 4,488.99 million has been disbursed as refinance facility from the fund till December 31, 2019. The facility is extended to the participating banks those who have signed agreement with BB to avail the fund. In OctoberDecember, 2019 quarter, highest Tk. 198.00 million was distributed in green industry and then Taka 132.50, 8.10, 0.24, 0.17and 0.16 million in ETPs, ensuring work environment and security of workers factories, biogas, solar home system and vermi compost respectively (Appendix 3).

5.2.2 ADB Supported Financing Brick Kiln Efficiency Improvement Project - "Financing Brick Kiln Efficiency Improvement Project" funded by Asian 
Development Bank (ADB) was established in 2012 for reducing greenhouse gas emissions and fine particulate pollution from brick fields of the country and building environment friendly brick field through efficiency development of brick kiln with appropriate use of energy. In this scheme, total amount of loan from ADB is 50.00 million USD/converted to equivalent BDT for local use (Appendix 2). Under this relending facility, Total \$50.01 million equivalent BDT 403.97 crore relending facility has been disbursed to 19 subprojects through 19 participating institutions till December, 2019. \$17.84 million equivalent BDT 147.21 crore has been disbursement to 05 subprojects through 09 PFIs during October-December quarter of FY2019-20. The tenure of the project ended in December 31, 2019.

\subsubsection{Refinance Scheme for Islamic Banks for Inve-} stment in Green Finance - Bangladesh Bank (BB) has introduced refinance scheme funded by excess liquidity of Sariah based financial institutions to facilitate the Sariah based banks in 2014. In 2018, BB has issued an integrated and comprehensive 'master circular' by revising and incorporating all the existing circular and circular letters related to this refinance scheme. BB has enhanced the product range under this scheme to 51 and segregated these products into 8 categories (Appendix 2). During October-December, 2019 quarter, BB has disbursed BDT 15.21 million for "Working Environment and Fire Safety of Factory" and collected BDT 0.32 million profit against this product.

5.2.4 Green Transformation Fund (GTF) - In January 2016, a longer-term refinancing window named Green Transformation Fund (GTF) of 200 million USD was launched to ensure sustainable growth in export oriented textile and leather sectors conducive to transformation of green economy in the country (Appendix 2). To further fortify the financing arrangement under GTF, it was decided to provision for a participation agreement to be signed between BB and intended banks. To widen the scope of this fund, it has been opened for all manufacturer-exporters irrespective of sectors against import of capital machinery and accessories for implementing specified green or environment-friendly initiatives since September, 2019 (Appendix 1).

\subsection{Analysis of Sustainable Development Initiatives by Banks and Financial Institutions}

5.3.1 Policy Formulation and Governance - All scheduled banks, except Community Bank Bangladesh Limited, have formed their own sustainable finance unit and green banking policy in accordance with guidelines given by Bangladesh Bank (BB).

5.3.2 Green Finance - As per the BB's Environmental Risk Management (ERM) guidelines, every bank has to adopt green banking initiatives. Banks were instructed by the BB to form a 'Climate Risk Fund (CRF)' having allocation at least $10 \%$ of their CSR budget for CRF to ensure the movement towards sustainability against the climate change. According to the guidelines set by the $\mathrm{BB}$, different banks disbursed different amount for their green banking purpose. In OctoberDecember, 2019 quarter, banks utilized 1.43\% of total funded loan disbursement as green finance. Green finance is, basically, provided to the areas of renewable energy, energy efficiency, alternative energy, waste management, recycling \& recyclable products, green brick manufacturing, green establishments etc. NRB Bank Limited has utilized highest $11.59 \%$ of its total funded loan disbursement as green finance in October-December, 2019 quarter.

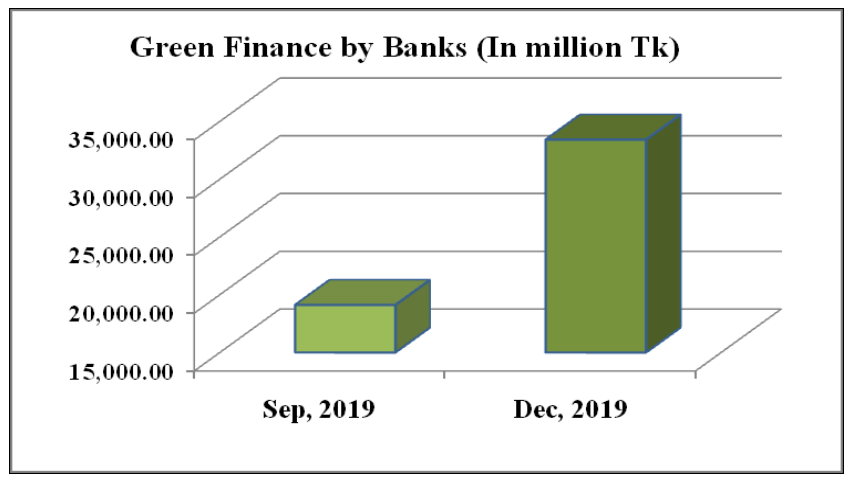

Fig 1: Quarterly comparison of green finance funded by banks.

Then $7.42 \%, 5.08 \%, 4.28 \%$ and $3.84 \%$ have been utilized by The HSBC Limited, BRAC Bank Limited, Mutual Trust Bank Limited and IFIC Bank Limited respectively (Appendix 6). The snapshot of sanction and disbursement of total finance along with green finance by banks evidences increasing trend in case of green finance and the utilization of climate risk fund. All 59 banks were sanctioned Tk. 79,925.13 million 
and finally disbursed Tk. 33,421.96 million in October-December, 2019 quarter. Among them, State Owned Commercial Banks (SOCBs) were disbursed Tk. 265.78 million against the sanction of Tk. 610.33 million. Private Commercial Banks (PCBs) Tk. 24,036.36 million against Tk. 70,183.82 million, Foreign Commercial Banks (FCBs) Tk. 9,113.01 million against Tk. 9,124.18 million and Specialized Development Banks Tk. 6.81 million against Tk. 6.81 million (Appendix 5). In the above Fig 1, it is clearly seen that green finance in the banking sector of Bangladesh is increasing day by day.

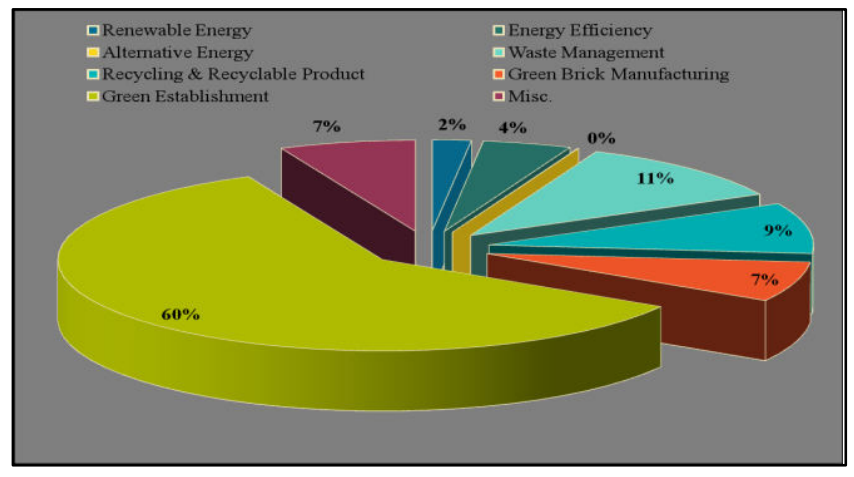

Fig 2: Green finance by banks in different sectors.

Total amount invested in green finance by banks is Tk. 33,421.96 million in October-December, 2019 quarter (Appendix 5). They are invested in renewable energy, alternative energy, recycling and recyclable products, green establishments, energy efficiency, waste management, green brick manufacturing etc. in the aforesaid percentages.

5.3.3 Climate Risk Fund Management - Banks have developed 'Climate Risk Fund (CRF)'as per the prescribed framework of BB. It is also observed that more or less, all banks consider both investment risk management and climate risk management while financing the project. In many cases, risk of climate changes has been integrated with credit appraisal procedure of banks. Climate risk fund has been utilized as grant by banks which is significantly higher than the previous quarter (Fig 3). In October-December, 2019 quarter, total Tk. 175.83 million has been invested by banks in 9different events and Tk. 4.50 million in 1 project. In all cases, private and foreign commercial banks utilized the full amount of money as climate risk fund. In the above Fig 2, climate risk fund is completely in the upward trend.

UniversePG I www.universepg.com

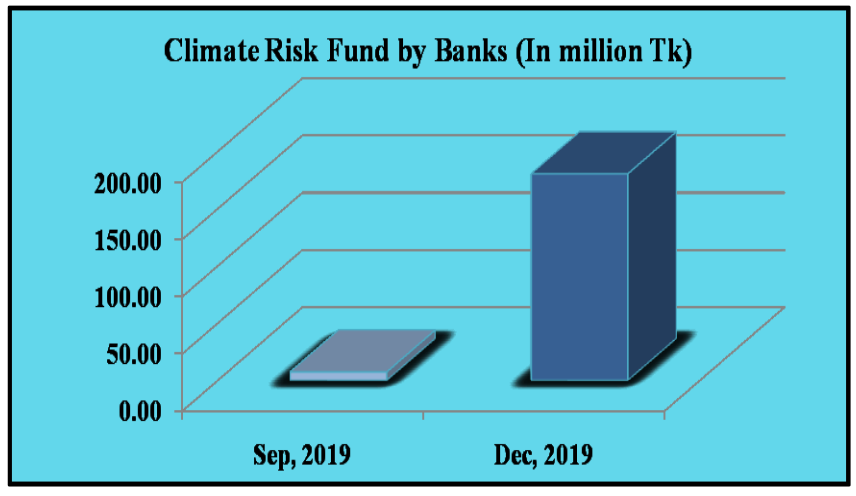

Fig 3: Utilization of climate risk fund by banks.

\subsubsection{Environmental and Social Risk Management -}

Almost all banks have developed environmental risk management guidelines as per the prescribed framework of BB. It is also observed that more or less, all banks consider both investment risk management and environmental risk management while financing the project. In many cases, risk of environmental has been integrated with credit appraisal procedure of banks. Banks always remain concerned about environmental risk rating.

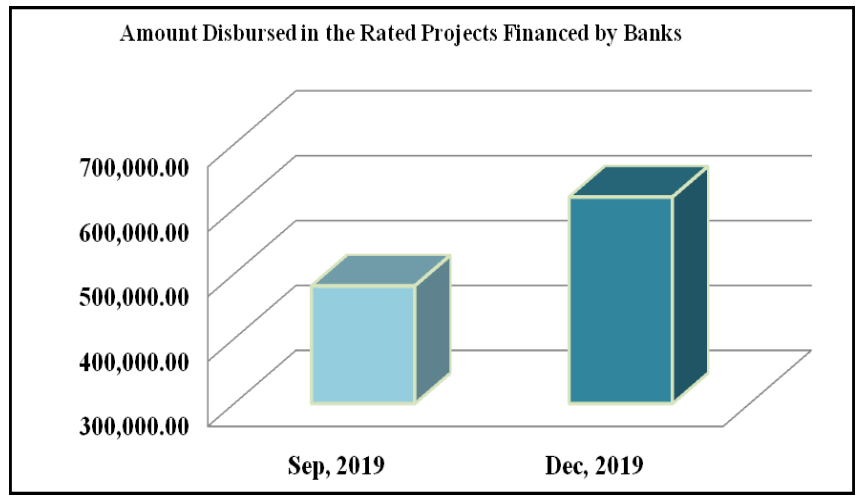

Fig 4: Quarterly comparison of environmental risk rating by banks.

40 banks out of 59 have conducted environmental risk rating in October-December, 2019 quarter. Tk. 6, 18, 270.35 million has been disbursed against 13, 926 rated projects in October-December, 2019 quarter.598 branches of banks are solar powered, 244 branches have developed solid waste management system, solar powered ATM both has been established in 76 branches and rainwater harvesting system has also been created in 7 branches of the banks in October-December, 2019 quarter (Appendix 7). $90 \%$ of all bank branches have also been brought under online banking in the reporting period (Appendix 8). 
5.3.5 In-house Environment Management - Measures have been taken by banks in reducing the consumption of water, electricity, fuel etc. As a part of it, the number of bank branches powered by solar energy stood at 598 at the end of 2019. As a part of waste management, they collect and dispose centrally both solid waste and e-wastes generated by their differrent units of operations through e-tendering with a view to ensuring an environment free from pollution. Tk. 3,731.39 million has been invested in waste management by banks till December 31, 2019. Banks have already started installation of solar panels at ATM booths and Fast Tracks as renewable energy. They use energy saving bulbs and energy efficient electronic equipment in offices. Tk. 644.31 million has been disbursed for renewable energy by banks in October-December, 2019 quarter.

To reduce the paper and stationary consumption, different banks have introduced the concept of soft archival of customer documents. Under this system electronic access and retrieval are enabling in the reduction of paper consumption. Now, most of the notes, internal memos, and records are in electronic form. Communications with customers are almost being done through SMS emails instead of letter communication. Video conferencing system has been introduced for telecommunication between the officials of the bank. Initiatives have also been taken to encourage the employees to undertake green travel for personal as well as business travel and has the arrangements of hybrid autos and carpooling system. Moreover, some banks developed policy not to finance enterprises involved in unethical businesses.

5.3.6 Online banking - State-of-the art technology is being used by many banks to provide various banking services without using paper such as mobile banking, internet banking, ATM or Fast Track, SMS banking, phone banking, credit card, debit card, call centre, Epayment, virtual card, e-payment gateway facilities and so on. Some banks are centralizing their corporate credit operations and preserving the different security documents of clients in the 'central vault' as an initiative of green banking practices and thereby paper consumption is reduced along with reducing the wastage of valuable time.

UniversePG I www.universepg.com

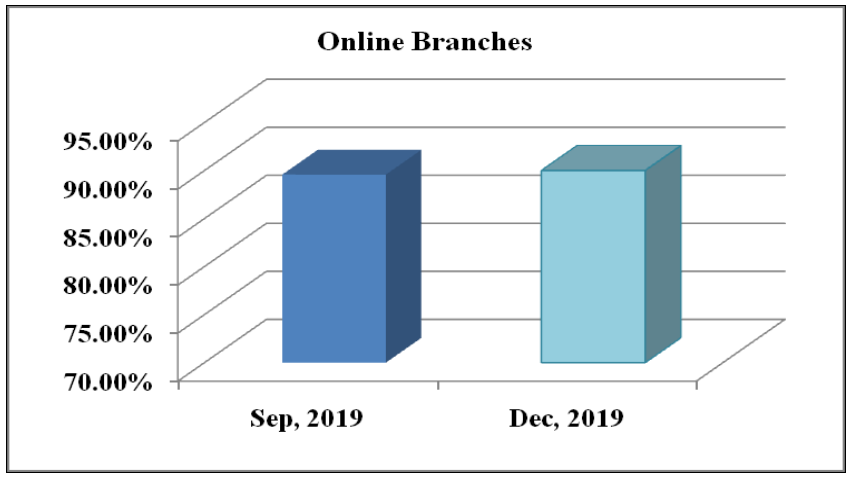

Fig 5: Online branches.

56 banks out of 59 have at least one online branch and 41 banks have introduced internet banking facility up to December, 2019. 90.00\% automation towards green banking has been observed in the expansion of online branches. Total 9,491 out of 10, 545 bank branches have online coverage in the reporting period. Among them Foreign Commercial Banks (FCBs) and Private Commercial Banks (PCBs) have about $100 \%$ online coverage. State Owned Commercial Banks (SOCBs) also has more than $98 \%$ coverage (Appendix 8)

\subsubsection{Training, Promotion and Disclosure - Many} banks organized pertinent and essential training and development programs like seminars, symposiums, discussion meetings, and workshops on environmental risk management and green banking. Some banks reported that their employees also participated time to time in many training programs organized by other institutions relating to the theme of sustainable or green banking issue. 33 banks have arranged 93 training programs concerning green banking where total number of participants was 3,392.

5.3.8 Green Strategic Planning - Few banks disclose that they have some annual green targets for which both strategic plans and budgets are duly approved. Each year they determine a set of green yearly targets. They also develop different means of materializing the actions, monitoring, supervision, evaluating the achievement, promotion and training/ awareness development programs. One of the banks disclosed its green banking budget quarter by quarter highlighting the areas of green banking in its green banking report. Another bank has set its green strategic planning with the target of reduction of (a) 5\% electricity, gas, and fuel consumption, (b) $10 \%$ paper consumption, (c) $5 \%$ GHG emission, and (d) 5\% electronic bills. 


\section{DISCUSSION:}

From the overall discussion, it can be said that green banking practice and its progress in Bangladesh are not at a satisfactory level as should be although the green banking activities of banks ended December 31, 2019 has experienced an upward trend in green finance. Green finance by banks has been increased by $74.94 \%$ in this quarter than the previous one. Few banks have surpassed the target of green finance compared to the total disbursement (5\%). As a 4th generation bank, NRB Bank Ltd. (11.39\%) has done an excellent job. Besides, The HSBC Ltd. (7.42\%) and Brac Bank Limited $(5.08 \%)$ have also done well. Even then, the overall situation of green banking is not good enough. As far as green banking is concerned throughout the world, Bangladeshi banks are far behind their counterparts from developed countries. The study highlights the fact that banks in Bangladesh is beginning to understand the importance of introducing green banking into their mainstream operations. Still, no bank in Bangladesh has been found in the UNEPs signatories of the Equator Principles, which is regarded as one of the most important standards for responsible financing.

The study shows that the banking sector in Bangladesh is in the diversification phase passing through the intensification and foundation phases. It is progressing steadily. Banks are engaged in in-house environment management and are contributing towards environment friendly finance. They have a lot more scope to contribute in the diversification of green finance in the way of sustainable development of Bangladesh. Online banking can increase the efficiency and profitability of a bank. It can lower the operation costs that result from paper overload. In fact, green banking is becom-ing mainstream as a way to make, save and lend money. But it is the result of a collective effort of all stakeholders. BB, as the central bank of the country, is trying to keep the balance at its level best through appropriate policy guidelines on green banking. BB is pursuing the banks to become more proactive to raise green finance. Refinance support from BB is also playing an important role to incentivize the green banking activities. As the outcome of these initiatives, green finance has been increased considerably compared to the previous quarter. It is expected that positive impact will be evidenced in the trend of green finance towards the sustainable development of Bangladesh by banks in gradual manner.

\section{CONCLUSION \& POLICY IMPLICATIONS:}

Bangladesh is one of the most climate change vulnerable countries in the world. Global warming is also posing a threat to Bangladesh seasonally and geographically. It is facing a lot of environment deteriorating problems like air pollution, water pollution and scarcity, deforestation, increasing disaster risk and loss of biodiversity. She is, now, in the most vulnerable situateion. Bangladesh will suffer significant losses if the situation does not change. At this moment, climate change is the most burning issue in the global context and changing global climate patterns, which are not only limited to extreme weather conditions, can cause changes to the seasonality and geography of many countries in the world. Average temperature increase due to global warming will cause loss of significant portion of our land due to rise of sea level in near future. So, it is high time to take steps in lowering carbon emission and establishing progressively more green projects. One of the productive ways, which was globally recognized and followed, is the introduction of green banking and funding on green projects. More likely green banking can aid Bangladesh to fight against global warming and lessen bad effects of climate changes. Moreover, in order to protect our future generation, we need to create pres-sure on global community to reduce global carbon dioxide emission. On the other hand, it is also the high time for the banking sector of Bangladesh to realize their responsibilities towards the environment as well as the society in order to compete and survive in the competitive market. BB, which has the legal power to shape the behavior of the banks, will have to force all the banks to implement green banking policy to curb its own environmental pollution, and reducing investment in environmentally harmful projects. Thus, green banking can play a significant role in implementing the broader concept of sustainable development of Bangladesh in the days coming. It is our expectation that our banking sector will play a strong intermediary role between economic development and environmental protection towards the sustainable development of Bangladesh in near future. 
The study has important theoretical and practical implications for the banking sector. Stakeholder, legitimacy, institutional and social contract theories vividly explain the motivations behind green banking of the country. Therefore, strong banking ensures transparency and competitive advantages while mitigating institutional and legitimacy gaps. This study has significant policy implications for policymakers of the country specifically the financial sector's regulatory authority and banks' management. The research can be used by the management as a tool for reviewing green banking practice and progress. Therefore, BB as a regulator can take consideration of the study for further development of green banking regulation in the country. Bangladesh is one of the severely affected countries of global environmental pollution. In line with global development and response to the global warming, green banking plays significant roles. Government as well as every bank should take initiatives in respect of green banking practices for protectting our environment. BB will emphasize with significance of green banking practices of a bank while according permission for opening new bank branches and approval for launching new bank. Government should also encourage the general people about the green banking practices. The central bank should monitor commercial banks whether they are practicing green banking or not. So, every bank has to participate and contribute to green banking practices in today's extreme national and global banking competition.

Banks should take initiative to set absolute greenhouse gas emission reduction targets from operations, energy use and business travel. Banks should also be engaged in financing Clean Development Mechanism (CDM) projects. For this, awareness of development and advisory services by banks in the process of developpment of CDM projects will be crucial. Banks should also take steps to form CRF to finance the economic activities in the flood, cyclone and drought prone areas. In case of environmental risk rating, banks need to apply a quantitative approach for a more justified rating along with Environmental Due Diligence (EDD) checklist under subjective criterion. They must speed up proper awareness and effective capacity building for the management at all levels of the banks and clients as well. They should take diversified activities especially introducing innovative products in the model of Bangladeshi infrastructure for a true green economy. Although Bangladesh have started its green journey lately, the hope is that a cooperative effort of banks and other stakeholders will contribute remarkably in coping with climate challenges and smoothen the path of sustainability in coming years. Besides, banks can do much more to help the environment than just promote online banking.

A truly green bank will reduce their carbon footprint by building more efficient branches, implementing energy-efficient operational procedures, offering transportation services for their employees, promoting sustainable banking and increasing their lending in environment-sensitive industries. It is necessary for organizations to attain sustainable competitive advantage by creating eco-friendly products. Banks can protect themselves as a socially and ethically oriented organization by disbursement of loans merely to those organizations, which has environmental concerns. Besides, Government should take necessary steps to enforce existing environmental regulations and formulate appropriate rules to ensure 'Pollute Pays Principle' in the country. BB can play a pro-active role in formulating a national level 'Green Credit Policy' and creating a sound incentive structure for performing environmental risk practices by banks. A discount window may encourage the banks to undertake green financing.

Banks in Bangladesh have already initiated various green banking actions and started practicing green banking. They can encourage their clients to invest on different green projects such as solar power generation project, alternate power generation project, electricity through wind mill, etc. Banks can familiarize and promote green banking initiatives as a part of their CSR activities. Privilege during loan approval and concession on loan can be given to the clients upon their investments on green projects or carbon lowering actions. BB has set mandatory rules and regulations for investment on green banking for all banks and they are bound to follow them strictly. This should be established considering that going green or practicing green banking and encouraging green projects will increase the brand value of banks which in turn will make them recognized globally. 


\section{ACKNOWLEDGMENTS:}

I thank the previous authors for their contributions in this field of study. I also thank all those senior officials of Bangladesh Bank and other Commercial Banks who have spent their valuable time in the informal interview.

\section{CONFLICTS OF INTEREST:}

There is no conflict of interest in the publication of this manuscript.

\section{REFERENCES:}

1. Ahmad, F., N.M. Zayed and M.A. Harun (2013). Factors behind the Adoption of Green Banking by Bangladeshi Commercial Banks. ASA University Review, 7(2): 241-255.

2. Argandona, A. (1998). The Stakeholder Theory and the Common Good, Journal of Business Ethics, 17(9/10): 1093-1102. https://doi.org/10.1023/A:1006075517423

3. Argenti, P. A. (2015). Corporate Communication; McGraw-Hill Higher Education: New York, NY, USA.

4. Bahl, S., (2012). The Role of Green Banking in Sustainable Growth. International Journal of Marketing, Financial Services \& Management Research, 2(2): 27-35.

5. Bangladesh Bank, (2019), Quarterly Review Report on Green Banking Activities, Sustainable Finance Department (SFD), OctoberDecember.

6. Berrone, P., Fosfuri, A., Gelabert, L. \& Gomez-Mejia, L.R. (2013). Necessity as the Mother of 'Green' Inventions: Institutional Pressures and Environmental Innovations. Strateg. Manag. J., 34: 891-909. https://doi.org/10.1002/smj.20411

7. Bhardwaj, B.R. and A. Malhotra, (2013). Green Banking Strategies: Sustainability through Corporate Entrepreneurship, Greener J. of Business and Management Studies, 3(4): 180193.

https://doi.org/10.15580/GJBMS.2013.4.122412 $\underline{343}$

8. Bihari, S.C., (2011). Green Banking-Socially Responsible Banking in India. India Banker, 6(1): 32-37.
9. Bose, S.; Khan, H.Z.; Rashid, A.; Islam, S. (2017). What Drives Green Banking Disclosure? An Institutional and Corporate Governance Perspective. Asia Pac. J. Manag., 1-27.

10. Chaurasia, A. K. (2014). Green Banking Practices in Indian Banks. JOMASS, 1(1): 41-54.

11. Chen, L.; Tang, O.; Feldmann, A. (2015). Applying GRI Reports for the Investigation of Environmental Management Practices and Company Performance in Sweden, China and India. J. Clean. Prod., 98: 36-46.

https://doi.org/10.1016/j.jclepro.2014.02.001

12. Chen, Z., Hossen, M. M., Muzafary, S. S. \& Begum, M. (2018). Green Banking for Environmental Sustainability-Present Status and Future Agenda: Experience from Bangladesh. Asian Econ. Finance. Rev. 8: 571. https://ideas.repec.org/a/asi/aeafrj/2018p571585.html

13. Chowdhory, M, A, A., \& Dey, M. (2016) Green Banking Practice in Bangladesh, The Cost and Management, 44(2): 34-39.

14. Choudhury, T. T., M. Salim, M. M. A. Bashir and P. Saha, (2013). Influence of Stakeholders in Developing Green Banking Products in Bangladesh, Research Journal of Finance and Accounting, 4(7): 67-77. http://citeseerx.ist.psu.edu/viewdoc/download?d oi=10.1.1.473.1362\&rep=rep1\&type $=$ pdf

15. Delgado-Márquez, B.L.; Pedauga, L.E.; Cordónpozo, E. (2016). Industries Regulation and Firm Environmental Disclosure: A Stakeholders' Perspective on the Importance of Legitimation and International Activities. Org. Environ., 1-19.

https://journals.sagepub.com/doi/abs/10.1177/10 $\underline{86026615622028}$

16. Dharwal, M. and A. Agarwal, (2013). Green Banking: An Innovative Initiative for Sustainable Development. 2(3): 1-5.

17. Dillard, J.F.; Rigsby, J.T.; Goodman, C. (2004). The Making and Remaking of Organization Context: Duality and the Institutionalization Process. Account. Audit. Account. J., 17: 506-542. 
18. Goyal, K. A. and V. Joshi, (2011). A Study of Social and Ethical Issues in Banking Industry. International Journal of Economic Research, 2(5): 49-57.

http://citeseerx.ist.psu.edu/viewdoc/download?d oi=10.1.1.472.4710\&rep=rep1\&type $=$ pdf

19. Gray, R.H., Owen, D. \& Adams, C. (1996). Accounting \& Accountability: Changes and Challenges in Corporate Social and Environmental Reporting; Prentice Hall: Upper Saddle River, NJ, USA. https://lib.ugent.be/catalog/rug01:000407455

20. Hossen, M.M., M.N. Uddin and A. Hossain, (2014). E-commerce: A Scrutiny about the Environmental Commerce through Upgrading the Environmental Sustainability. BUP J., 1(2): 83-103.

21. Iqbal, M., Nisha, N., Rifat, A. \& Panda, P. (2018). Exploring Client Perceptions and Intentions in Emerging Economies: The Case of Green Banking Technology. Int. J. Asian Bus. Inf. Manag. 9: 14-34. https://doi.org/10.4018/IJABIM.2018070102

22. Islam MJ, Roy SK, Miah M, and Das SK. (2020). A review on corporate environmental reporting: an emerging issue in the corporate world, Can. J. Bus. Inf. Stud., 2(3), 45-53. https://doi.org/10.34104/cjbis.020.045053

23. Khan, A.; Muttakin, M.B.; Siddiqui, J. (2013), Corporate Governance and Corporate Social Responsibility Disclosures: Evidence from an Emerging Economy. J. Bus. Ethics. 114:207223. https://doi.org/10.2139/ssrn.2050630

24. Masud, M. A., Bae, S.; Kim, J. (2017). Analysis of Environmental Accounting and Reporting Practices of Listed Banking Companies in Bangladesh, Sustainability. 9(17), 1717. https://doi.org/10.3390/su9101717

25. Masud, M., Hossain, M., \& Kim, J. (2018). Is Green Regulation Effective or a Failure: A Comparative Analysis between Bangladesh Bank (BB) Green Guidelines and Global Reporting Initiative Guidelines, Sustainability, 10(4):1267. https://doi.org/10.3390/su10041267

26. Meena, R., (2013). Green Banking as Initiative for Sustainable Development, Global Journal of Management and Business Studies, 3(10): 1181-1186.

https://www.ripublication.com/gjmbs_spl/gjmbs v3n10_21.pdf

27. National Sustainable Development Strategy (NSDS) (2020). Planning Commission, Government, People's Republic of Bangladesh 20102021.

28. Ntim, C.G.; Lindop, S.; Thomas, D.A. (2013). Corporate Governance and Risk Reporting in South Africa: A Study of Corporate Risk Disclosures in the Pre- and Post-2007/2008 Global Financial Crisis Periods. Int. Rev. Financ. Anal., 30: 363-383. https://doi.org/10.1016/j.irfa.2013.07.001

29. Oliver, C. (1991). Strategic Responses to Institutional Processes. Acad. Manag. Rev., 16: 145-179.

https://journals.aom.org/doi/10.5465/amr.1991.4 279002

30. Ortiz-de-Mandojana, N., Aguilera-Caracuel, J. \& Morales-Raya, M. (2016). Corporate Governance and Environmental Sustainability: The Moderating Role of the National Institutional Context. Corp. Soc. Respons. Envir. Manag., 23: 150-164. https://doi.org/10.1002/csr.1367

31. Perrault, E. \& Clark, C. (2016). Environmental Shareholder Activism: Considering Status and Reputation in Firm Responsiveness Organization. Org. Environ., 29: 194-211.

https://journals.sagepub.com/doi/10.1177/10860 26615571939

32. Rahman, F. \& Perves, M. M. (2016). 'Green Banking Activities in Bangladesh: An Analysis and Summary of Initiatives of Bangladesh Bank', Research Journal of Finance and Accounting, 7(10): 6-7.

https://iiste.org/Journals/index.php/RJFA/article/ view/30360

33. Rahman MM., and Rahman MS. (2020). Green reporting as a tool of environmental sustainability: some observations in the context of Bangladesh, Int. J. Manag. Account. 2(2), 31-37. https://doi.org/10.34104/ijma.020.031037

34. Rahman, M.M., A.M. Ahsan, M.M. Hossain and M.R. Hoq, (2013). Green Banking Pros- 
pects in Bangladesh, Asian Business Review, 2(2): 59-63.

35. Rousseau, Jean-Jacques. (1987). The Basic Political Writings. (Trans. Donald A. Cress) Hackett Publishing Company.

36. Saha S, Sarker R, and Ahmed SM. (2020). Impact of Green Human Resource Management (GHRM) practices in garment industry: Bangladesh perspective, Int. J. Manag. Account. 2(2), 22-30. https://doi.org/10.34104/ijma.020.022030

37. Sellito et al. (2019), Green human resource management and environmental cooperation: An ability-motivation-opportunity and contingency perspective. International Journal of Production Economics, 91: 219.
38. Smith, Charles and Rees, Gareth, (1998). Economic Development, $2^{\text {nd }}$ Edition, BasingStoke: Macmillan. 237 Pages.

39. Ullah, Md. Maruf, (2013). Green Banking in Bangladesh-A Comparative Analysis, World Review of Business Research, 3(4): 74-83.

40. UNCED, (1992). United Nations Conference on Environment and Development (UNCED) held in Rio de Janerio in 1992.

https://www.un.org/en/conferences/environment/ rio1992

41. Weber, O. and S. Remer, (2011). Social Banks and the Future of Sustainable Finance. New York: Routledge. 252 Pages. https://www.routledge.com/Social-Banks-andthe-Future-of-Sustainable-Finance/Weber-Rem er/p/book/9781138799493

\section{APPENDICES}

Appendix 1: Policy (Circular) Guidelines by Bangladesh Bank (2011-2019)

\begin{tabular}{|c|c|c|}
\hline Year & Policy & Circular \\
\hline 2011 & $\begin{array}{l}\text { Environmental Risk Management (ERM) Guidelines for Banks and Financial } \\
\text { Institutions has been issued. }\end{array}$ & $\begin{array}{l}\text { BRPD Circular No. } \\
01 / 2011\end{array}$ \\
\hline 2011 & Green Banking Policy Guidelines for Banks has been issued. & $\begin{array}{l}\text { BRPD Circular } \\
\text { No.02/2011 }\end{array}$ \\
\hline 2012 & $\begin{array}{l}\text { A uniform reporting format for reporting green banking activities for banks was } \\
\text { introduced. }\end{array}$ & $\begin{array}{l}\text { BRPD Circular } \\
\text { Letter No. 07/2011 }\end{array}$ \\
\hline 2013 & $\begin{array}{l}\text { Policy Guidelines for Green Banking was also issued for the Financial Institutions } \\
\text { (FIs) and for the banks scheduled in } 2013\end{array}$ & $\begin{array}{l}\text { GBCSRD Circular } \\
\text { Letter No. } 05 / 2013\end{array}$ \\
\hline 2014 & $\begin{array}{l}\text { From January } 2016 \text { onwards minimum target of direct green finance was set at } 5 \% \text { of } \\
\text { the total funded loan disbursement/investment for all banks and FIs. }\end{array}$ & $\begin{array}{l}\text { GBCSRD Circular } \\
\text { No. } 05 / 2014\end{array}$ \\
\hline 2015 & $\begin{array}{l}\text { Banks and FIs were instructed to form a 'Climate Risk Fund' having allocation at least } \\
10 \% \text { of their Corporate Social Responsibility budget. }\end{array}$ & $\begin{array}{l}\text { GBCSRD Circular } \\
\text { No. } 04 / 2015\end{array}$ \\
\hline 2016 & $\begin{array}{l}\text { Banks \& FIs have been instructed to set up Solid Waste Management System, } \\
\text { Rainwater Harvesting and Solar Power Panel in their newly constructed or arranged } \\
\text { building infrastructure. }\end{array}$ & $\begin{array}{l}\text { SFD Circular No. } \\
01 / 2016\end{array}$ \\
\hline 2016 & $\begin{array}{l}\text { All the banks \& FIs must ensure the establishment and activeness of Effluent } \\
\text { Treatment Plant (ETP) during financing to all possible clients. }\end{array}$ & $\begin{array}{l}\text { SFD Circular No. } \\
03 / 2016\end{array}$ \\
\hline 2016 & $\begin{array}{l}\text { All banks and FIs to establish Sustainable Finance Unit and Sustainable Finance } \\
\text { Committee by abolishing both Green Banking and CSR units. }\end{array}$ & $\begin{array}{l}\text { SFD Circular No. } \\
02 / 2016\end{array}$ \\
\hline 2017 & $\begin{array}{l}\text { Guidelines on Environmental and Social Risk Management (ESRM) for Banks and } \\
\text { Financial Institutions along with an Excel-based Risk Rating Model have been issued. }\end{array}$ & $\begin{array}{l}\text { SFD Circular No. } \\
02 / 2017\end{array}$ \\
\hline 2017 & $\begin{array}{l}\text { A comprehensive list of product/initiatives of Green Finance for banks and FIs has } \\
\text { been circulated. }\end{array}$ & $\begin{array}{l}\text { SFD Circular No. } \\
04 / 2017\end{array}$ \\
\hline 2018 & $\begin{array}{l}\text { A new uniform reporting format of Quarterly Review Report on Green Banking } \\
\text { Activities has been circulated for Banks \& FIs to monitor green banking policy \& other } \\
\text { regulations and to ensure the quality \& uniformity of data provided by Banks \& FIs. }\end{array}$ & $\begin{array}{l}\text { SFD Circular No. } \\
01 / 2018\end{array}$ \\
\hline 2019 & Investment by scheduled banks \& FIs in any impact fund which is registered under & SFD Circular No. \\
\hline
\end{tabular}




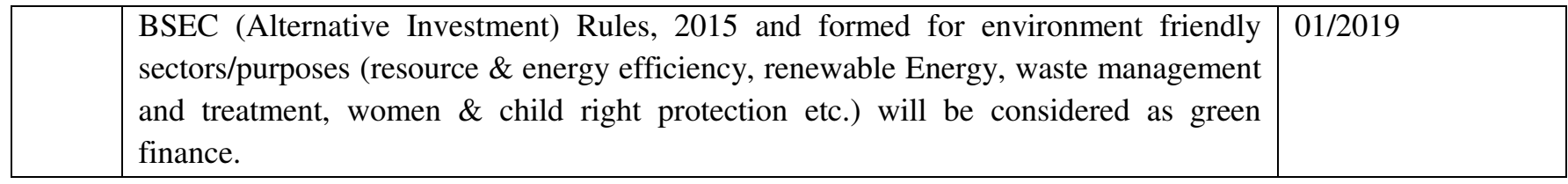

Source: Quarterly Review Report on Green Banking Activities, Sustainable Finance Department (SFD), Bangladesh Bank, October-December, 2019

Appendix 2: Refinance (Support Funding) Scheme of BB for Green Finance

\begin{tabular}{|l|l|l|l|}
\hline $\begin{array}{l}\text { BB Refinance Scheme for } \\
\text { Environment Friendly } \\
\text { Products/Initiatives }\end{array}$ & $\begin{array}{l}\text { ADB Supported } \\
\text { Financing Brick Kiln } \\
\text { Efficiency Improvement } \\
\text { project }\end{array}$ & $\begin{array}{l}\text { Refinance Scheme for } \\
\text { Islamic Banks \& Financial } \\
\text { Institutions } \\
\text { for Green Finance }\end{array}$ & Green Transformation Fund \\
\hline $\begin{array}{l}\text { Tk } 2.00 \text { billion funded by } \\
\text { BB as Revolving Fund } \\
\text { available for } 51 \text { green } \\
\text { products/initiatives in } 8 \\
\text { categories. }\end{array}$ & $\begin{array}{l}\text { USD 50.00 billion } \\
\text { funded by ADB as } \\
\text { Revolving Fund available } \\
\text { for „Green Brick Field }\end{array}$ & $\begin{array}{l}\text { Funded by excess liquidity } \\
\text { of Shariah Based Banks \& } \\
\text { products/initiatives in } 8 \\
\text { categories. }\end{array}$ & $\begin{array}{l}\text { USD } 200 \text { million funded by available for all the } \\
\text { export oriented sector } \\
\text { against import of energy } \\
\text { efficient machineries. }\end{array}$ \\
\hline
\end{tabular}

Source: Quarterly Review Report, SFD, Bangladesh Bank, October-December, 2019

Appendix 3: Environment Friendly Product wise Disbursement

\begin{tabular}{|c|l|c|}
\hline SN No. & \multicolumn{1}{|c|}{ Products } & Taka in Million \\
\hline 1 & Biogas & 0.24 \\
\hline 2 & Effluent Treatment Plant (ETP) & 132.50 \\
\hline 3 & Vermi compost & 0.16 \\
\hline 4 & Green industry & 198.70 \\
\hline 5 & Ensuring work environment and security of workers & 8.10 \\
\hline 6 & Solar Home System & 0.17 \\
\hline \multicolumn{1}{|c|}{ Total Disbursement } & 339.87 \\
\hline
\end{tabular}

Source: Quarterly Review Report, SFD, Bangladesh Bank, October-December, 2019

Appendix 4: Funding Schemes of Bangladesh Bank for Green Finance

\begin{tabular}{|c|c|c|}
\hline SN No. & Funding scheme of BB & Taka in Million \\
\hline 1 & $\begin{array}{l}\begin{array}{l}\text { Disbursement from } \\
\text { Products/Initiatives }\end{array} \\
\end{array}$ & 339.87 \\
\hline 2 & $\begin{array}{lllllll}\begin{array}{l}\text { Disbursement from } \\
\text { Improvement project }\end{array} & & & \text { ADB } & \text { Supported } & \text { Financing } & \text { Brick Kiln Efficiency } \\
\end{array}$ & 1472.1 \\
\hline 3 & $\begin{array}{l}\text { Disbursement from Refinance Scheme for Islamic Banks \& Financial Institutions } \\
\text { for Investment in Green Products/Initiatives }\end{array}$ & 15.21 \\
\hline 4 & Disbursement from Green Transformation Fund (GTF) & 19.73 \\
\hline
\end{tabular}

Source: Quarterly Review Report, SFD, Bangladesh Bank, October-December, 2019

Appendix 5: Sanction \& Disbursement of Green Finance (Funded)

\begin{tabular}{|l|c|c|}
\hline \multicolumn{1}{|c|}{ Type of Banks/FIs } & Sanctioned & Disbursed \\
\hline State Owned Commercial Banks (SOCBs-06) & 610.33 & 265.78 \\
\hline Special Development Banks (SDBs-03) & 6.81 & 6.81 \\
\hline Private Commercial Banks (PCBs-41) & $70,183.82$ & $24,036.36$ \\
\hline Foreign Commercial Banks (FCBs-09) & $9,124.18$ & $9,113.01$ \\
\hline Banks' Total (59) & $\mathbf{7 9 , 9 2 5 . 1 3}$ & $\mathbf{3 3 , 4 2 1 . 9 6}$ \\
\hline
\end{tabular}

Source: Quarterly Review Report, SFD, Bangladesh Bank, October-December, 2019

UniversePG I www.universepg.com 
Appendix 6: Top 5 Banks in Green Finance

\begin{tabular}{|c|l|c|}
\hline SN No. & \multicolumn{1}{|c|}{ Name of Banks } & Green finance as \% of total funded loan disbursement \\
\hline 1 & NRB Bank Limited & $11.39 \%$ \\
\hline 2 & The HSBC Bank Limited & $7.42 \%$ \\
\hline 3 & BRAC Bank Limited & $5.08 \%$ \\
\hline 4 & Mutual Trist Bank Limited & $4.28 \%$ \\
\hline 5 & IFIC Bank Limited & $3.84 \%$ \\
\hline
\end{tabular}

Source: Quarterly Review Report, SFD, Bangladesh Bank, October-December, 2019

Appendix 7: Environmental Conservation in Business Centers

\begin{tabular}{|l|c|c|c|c|c|c|}
\hline $\begin{array}{c}\text { Type of } \\
\text { Bank/FI }\end{array}$ & $\begin{array}{c}\text { No. of } \\
\text { Branches }\end{array}$ & $\begin{array}{c}\text { No. of branches } \\
\text { powered by } \\
\text { Solar Energy }\end{array}$ & $\begin{array}{c}\text { No. of } \\
\text { ATM } \\
\text { Booths }\end{array}$ & $\begin{array}{c}\text { No. of ATM } \\
\text { Booths powered } \\
\text { by Solar Energy }\end{array}$ & $\begin{array}{c}\text { Number } \\
\text { of Agent } \\
\text { Outlets }\end{array}$ & $\begin{array}{c}\text { Number of Solar } \\
\text { Powered Agent } \\
\text { Outlets }\end{array}$ \\
\hline SOCBs(06) & 3,777 & 76 & 240 & 2 & 200 & 0 \\
\hline SDBs (03) & 1415 & 5 & 6 & 0 & 0 & 0 \\
\hline PCBs (40) & 5,283 & 512 & 7046 & 63 & 26,437 & 5 \\
\hline FCBs (09) & 64 & 5 & 139 & 11 & 0 & 0 \\
\hline Banks' Total & 10,545 & 598 & 7431 & 76 & 26,637 & 5 \\
\hline
\end{tabular}

Source: Quarterly Review Report, SFD, Bangladesh Bank, October-December, 2019

Appendix 8: Automation towards Green Banking

\begin{tabular}{|l|c|c|c|c|}
\hline \multicolumn{1}{|c|}{ Type of Banks } & No. of Banks & $\begin{array}{c}\text { No. of Total } \\
\text { Branches }\end{array}$ & $\begin{array}{c}\text { No. of branches with } \\
\text { online coverage }\end{array}$ & \% of Online Branches \\
\hline SOCBs & 06 & 3,777 & 3,706 & $98.12 \%$ \\
\hline SDBs & 03 & 1,421 & 439 & $30.89 \%$ \\
\hline PCBs & 41 & 5,283 & 5282 & $99.98 \%$ \\
\hline FCBs & 09 & 64 & 64 & $100.00 \%$ \\
\hline Total & 59 & 10,545 & 9,491 & $90.00 \%$ \\
\hline
\end{tabular}

Source: Quarterly Review Report, SFD, Bangladesh Bank, October-December, 2019

Appendix 9: Training

\begin{tabular}{|l|c|c|c|c|}
\hline \multicolumn{1}{|c|}{ Type of Banks/FIs } & No. of Banks & No. of Programs & No. of Employees & No. of Customers \\
\hline SOCBs & 06 & 08 & 144 & 00 \\
\hline SDBs & 03 & 06 & 165 & 00 \\
\hline PCBs & 41 & 73 & 2791 & 10 \\
\hline FCBs & 09 & 06 & 282 & 00 \\
\hline Total & 59 & 93 & 3,382 & 10 \\
\hline
\end{tabular}

Source: Quarterly Review Report, SFD, Bangladesh Bank, October-December, 2019

Citation: Ullah MA. (2020). Green banking in the way of sustainable development: an overview of practice and progress in Bangladesh, Can. J. Bus. Inf. Stud., 2(5), 105-119.

https://doi.org/10.34104/cjbis.020.01050119 क @ 